\title{
Retinal ischemia as the first manifestation of antiphospholipid antibody syndrome
}

\author{
Isquemia retiniana como primeira manifestação \\ da síndrome do anticorpo antifosfolipídio
}

Giovanna Maria Oliveira Ribeiro1 https://orcid.org/0000-0002-5760-9787

Carlos Eduardo Engel Velano ${ }^{2}$ https://orcid.org/0000-0002-6980-7297

Cleiton Cardoso Ribeiro ${ }^{3}$ https://orcid.org/0000-0003-4525-1244

Flávia Beatriz de Andrade Oliveira Ribeiro ${ }^{4}$ https://orcid.org/0000-0001-6921-1218

\begin{abstract}
Antiphospholipid antibody syndrome (APS) is characterized by the development of venous and/or arterial thrombosis and by gestational morbidity (recurrent fetal losses) in the presence of antiphospholipid antibodies. We report the case of a 38-year-old woman who was diagnosed with primary APS from thromboembolic abnormalities in the retinal periphery that led to retinal ischemia. The aim of this study is to share with physicians and medical undergraduates an atypical manifestation of the syndrome that is the most common acquired thrombophilia, that should be part of the diagnostic routine of all clinical specialties.
\end{abstract}

Keywords: Ischemia; Antiphospholipid syndrome; Retina; Thrombosis; Antibodies, anticardiolipin; Autoantibodies.

\section{RESUMO}

A síndrome do anticorpo antifosfolipídio (SAAF) caracteriza-se pelo desenvolvimento de tromboses venosas e/ou arteriais e pela morbidade gestacional (perdas fetais recorrentes) na presença de anticorpos antifosfolipídicos. Foi relatado o caso de uma paciente de 38 anos que foi diagnosticada com SAAF primária, a partir de alterações tromboembólicas na periferia da retina, que levaram à isquemia retiniana. $\mathrm{O}$ objetivo desse estudo é compartilhar com médicos e acadêmicos de medicina uma manifestação atípica da síndrome que é a trombofilia adquirida mais comum, devendo fazer parte da rotina diagnóstica de todas as especialidades clínicas.

Descritores: Isquemia; Síndrome antifosfolipídica; Retina; Trombose; Anticorpos anticardiolipina; Autoanticorpos.

\footnotetext{
${ }^{1}$ Academic Medical Course, Universidade José do Rosário Vellano, UNIFENAS, Alfenas, MG, Brazil. ${ }^{2}$ Hematology Discipline, Universidade José do Rosário Vellano, UNIFENAS, Alfenas, MG, Brazil. ${ }^{3}$ Oftalmoclínica Costa Ribeiro, Alfenas, MG, Brazil.

${ }^{4}$ Ophthalmology Department, Universidade José do Rosário Vellano, UNIFENAS, Alfenas, MG, Brazil.
}

This study was performed at Universidade José do Rosário Vellano, UNIFENAS, Alfenas, MG, Brazil.

Research Ethics Committee Number - José do Rosário Vellano University - CAAE: 08113919.9.0000.5143

The authors declare no conflict of interest

Received for publication 24/1/2020 - Accepted for publication 15/5/2020. 


\section{INTRODUCTION}

$\mathbf{T}$ he retina may develop ischemic conditions when there is severe blood loss or vascular occlusion. APS is not among the main etiologies of retinal ischemia; however, it may lead to this manifestation.

APS is a systemic autoimmune disease characterized by recurrent arterial or venous thrombosis and / or gestational morbidity accompanied by the persistent presence of antiphospholipid antibodies (aPL). The most common manifestation of this syndrome is deep vein thrombosis (DVT). ${ }^{(1)}$

However, the presentation of APS varies widely, depending on the thrombosis location and vessel caliber. It is important to emphasize that small vessel occlusions may occur, but they are not usually the main highlight of the clinical picture; however, patients with microvascular antiphospholipid antibody syndrome (MAPS) have only minor microvascular manifestations. Thus, retinal ischemia, such as those presented by the patient, are not usually the first manifestation. ${ }^{(2)}$

We will report the case of a 38-year-old woman who was diagnosed with primary APS from thromboembolic abnormalities in the retinal periphery. The aim of this paper is to share with physicians and medical academics an atypical manifestation of APS, which is the most common acquired thrombophilia, that should be part of the diagnostic routine of all clinical specialties.

This study was approved by Research Ethics Committee Number - José do Rosário Vellano University - CAAE: 08113919.9.0000.5143.

\section{Case report}

In May 2013, a 33-year-old woman complained of right eye (RE) spotting vision two days ago. She denied pain and systemic diseases, and no conjunctival hyperemia and discharge was observed. On examination, she presented vitreous hemorrhage in RE. Indirect fundus was repeated five days later and there was almost complete resorption of the vitreous hemorrhage. After one month, the fundus examination was repeated and an area of inferior vitreous hemorrhage, optic disc vascular changes, and inferior vascular arch were found in RE; in the left eye (LE), vascular changes on the optic disc and retinal periphery were found. The patient was referred to a retina specialist evaluation. A search for hyperhomocysteinaemia secondary to a decrease in vitamin B12 and folic acid was initiated. The patient had undergone bariatric surgery in 2012, Roux-en-Y gastroplasty (FOBI-CAPELLA). Serum homocysteine (Hcy) levels were slightly elevated at the moment of the first examination, but there was no vitamin deficiency. After one month, the amino acid concentration had normalized.

Evaluation with the retina specialist resulted in the finding of a peripheral vascular thromboembolic process affecting bilateral microvasculature with an angiographic picture compatible with the process described above. Intravitreal antiangiogenic was indicated for both eyes. After one week of medication, laser photocoagulation was performed on the peripheral retina of both eyes. Patient underwent extensive protocols of thromboembolism, with investigation of thrombophilias or cardioembolic causes. Cardiac evaluation revealed no alterations with a normal electrocardiogram. Results were negative for APS, prothrombin gene mutation and Leiden factor $\mathrm{V}$ mutation. Doppler ultrasound of the carotid, vertebrobasilar, renal, and lower limbs arteries was normal. Laboratory tests for viral hepatitis were negative and there were no changes in collagen research. Hematologist indicated the use of a platelet antiaggregant.

A fluorescent angiography was performed, with the following result: cauterization of the lower and upper extreme temporal periphery by laser, but an increase in the infarcted area could be observed, initiating involvement of the middle periphery and nasal periphery. Neovascular discs were also observed, with severe extravasation in the late phases. An intravitreal antiangiogenic injection complemented with laser photocoagulation was also accomplished.

In 2014, a control flurescein angiography was performed, showing vascular microangiopathy (Figure 1 and 2). A new intravitreal antiangiogenic injection complemented with laser photocoagulation was performed.

After 3 years, the patient returns reporting transitory episodes of visual blurring in both eyes, especially in LE. The patient underwent protocols to investigate the causes of thromboembolic phenomena in a health service in São Paulo, but no changes were found. On examination, she had a RE with a laser photocoagulated periphery. In LE there was moderate vitreous hemorrhage. Laboratory tests, simple retinography and fluorescent angiography were requested again.

In May 2018, the patient maintains with a low vision in LE,



Figure 1. Papillary neovessels.

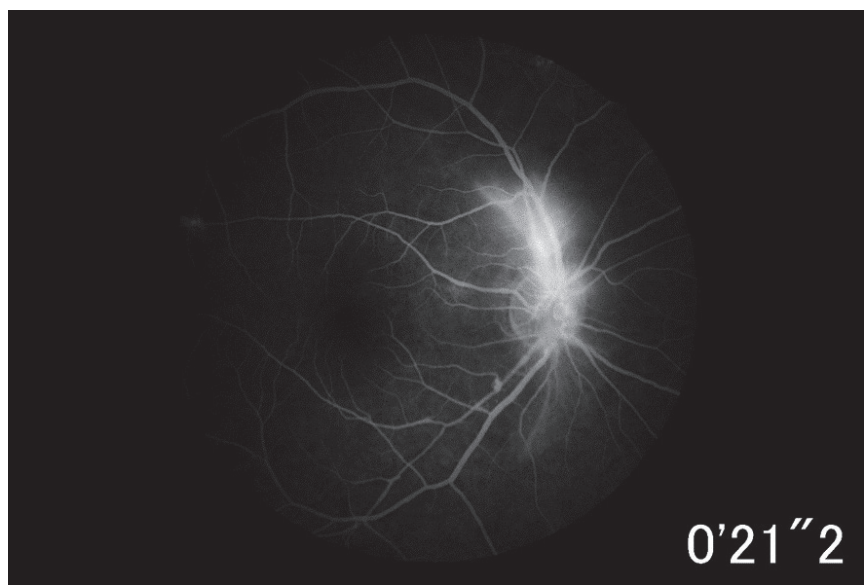

Figure 2. Hyperfluorescent areas caused by papillary neovessels.

reports episodes of anemia, but at this moment laboratory tests were without changes. On examination, the patient presents RE with laser photocoagulated periphery. In LE, she shows laser photocoagulated periphery, inferior area of vitreous condensation and vitreous hemorrhage. Simple retinography and fluorescent angiography, macula optical coherence tomography and serology for antiphospholipid antibodies were requested.

Simple retinography and fluorescent angiography revealed proliferative retinal papillary retinopathy and poor peripheral perfusion in both eyes (Figure 3 ).

The outcome of the optical coherence tomography was 
the presence of macular edema in both eyes, more intense in RE. Panphotocoagulation was indicated and a hematologist evaluation was requested for assessment of antiphospholipid antibody syndrome.

Assessment with the hematologist revealed thromboembolic phenomena in the retinal periphery in both eyes, and recurrent iron deficiency anemia. The patient had intense menstrual flow, perversion of appetite, and in venous use of warfarin. She denied pregnancy and cigarette smoking.

Blood test results was as follows: Hemoglobin $10.6 \mathrm{~g} \%$; He-

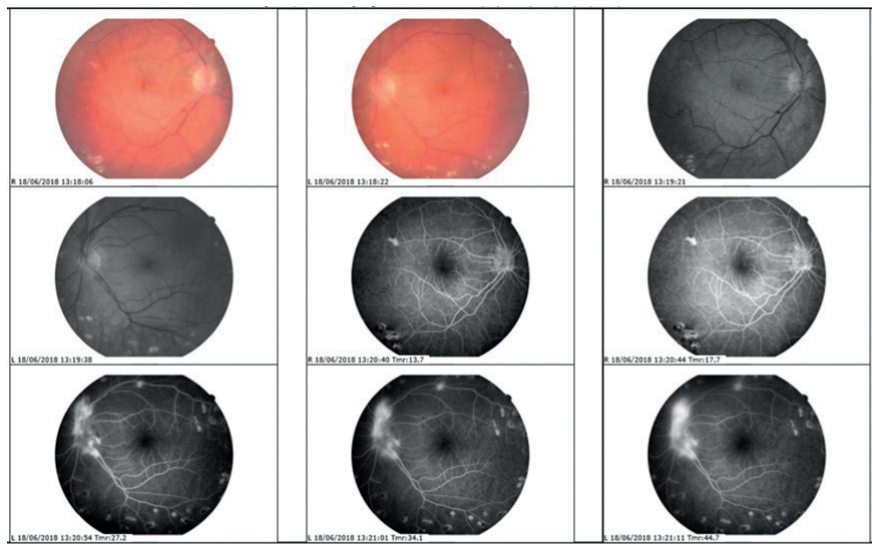

Figure 3. Presence of papillary and peripherally neovessels, causing hyperfluorescence. Laser marks around the vascular arch

matocrit 33\%; VCM 75 fL; HCM 24 pg; Leukocytes 5400 / mm3; Neutrophils 53\%; Platelets 333,000 / mm3.

Thrombophilia was suspected and a full blood count, with ferritin, vitamin B12, folic acid and aPL dosages, was requested.

In August 2018, the exams indicated the presence of lupus anticoagulant. Thus, the patient was diagnosed with APS and started treatment with antiplatelet therapy.

\section{Discussion}

Given the clinical condition of retinal ischemia in a patient without comorbidities, we considered the hypothesis of hyperhomocysteinemia, due to the previous history of bariatric surgery. Homocysteine (Hcy) is a sulfur amino acid derived from methionine metabolism and its slightly increased concentration is a risk factor for the development of vascular diseases, as it can lead to endothelial dysfunction and increased prothrombotic factors. ${ }^{(3,4)}$ Hyperhomocysteinemia may be caused by a deficiency of folic acid, vitamin B12 and B6 because they are important elements in Hcy metabolism. ${ }^{(3)}$ However, the patient did not have theses nutritional deficiencies, which indicates that the elevation of this amino acid may have been due to drug interactions.

Next, we investigated cardioembolic causes or thrombophilias, such as APS, which is an acquired autoimmune thrombophilia characterized by the presence of a heterogeneous family of antibodies called antiphospholipid antibodies. These bind to phospholipids and proteins (serum or plasma membrane) which are expressed or linked in endothelial cells, platelets, monocytes and fibroblasts. ${ }^{(5-7)}$ This association alters the procoagulant, anticoagulant mechanisms and secretion of various molecules, generating thrombotic events. ${ }^{(6)}$ In addition, there is a genetic component related to the human leukocyte antigen (HLA) class II system that may predispose the individual to the disease. However, this mechanism still needs to be elucidated. ${ }^{(7)}$

To diagnose this syndrome, at least one clinical criterion (thrombotic event or gestational morbidity) and one laboratory criterion are required. ${ }^{(7)}$ Laboratory criteria include the dosage of anticardiolipin antibodies (aCL), anti- $\beta 2$-glycoprotein I antibody or lupus anticoagulant (LA), where LA is the most specific test and aCL is the most sensitive. Blood samples should be collected on two or more occasions, at least 12 weeks apart. ${ }^{(6.2)}$

The patient had both tests negative in the initial exams. However, it should be noted that dosages were performed at an interval of less than 12 weeks. In a second moment, the exams indicated the presence of LA. Adding this laboratory criterion with the clinical one, which consisted of thromboembolic phenomena on the peripheral retina of both eyes, the diagnosis of APS was confirmed.

One concludes that APS is a challenge for health professionals. Although laboratory tests are of fundamental importance for diagnosis, they have limitations associated with robustness, reproducibility and standardization. The high sensitivity in detecting aCL favors the diagnosis, but there is still the problem of lack of specificity and the high number of false positive results. ${ }^{(5)}$ On the other hand, it is important that professionals be aware of atypical clinical manifestations, such as the case reported here, in which the initial picture was retinal ischemia.

\section{Acknowledgments}

This project was supported by the Institutional Program of Scientific Initiation Scholarships from UNIFENAS, Alfenas, MG, Brazil.

\section{RefERENCES}

1. Funke A, Danowski A, de Andrade D, Rêgo J, Levy RA. A importância de reconhecer a síndrome antifosfolípide na medicina vascular. J Vasc. Bras. 2017; 16(2): 140-9.

2. Lopes AC. Tratado de clínica médica. 3a ed. Rio de Janeiro: Roca; 2016.

3. Moreira DS. Ácido acetilsalicílico como estratégia neuroprotetora em ratos submetidos à hiperhomocisteinemia leve: avaliações neuroquímicas e morfológicas [dissertação]. Porto Alegre: Universidade Federal do Rio Grande do Sul; 2017.

4. Ling-Cong, Hong-Zhao, Yu- Wang, Yu-Li, Xin-Sui. The serum homocysteine level in patients with acute ischemic stroke (AIS) after thrombolysis and its relationship with clinical outcomes. Rev Assoc Med Bras. 2018; 64(5):438-42.

5. Dusse LM, Silva FD, Freitas LG, Rios DR, Armond SC, Marcolino MS. Antiphospholipid syndrome: a clinical and laboratorial challenge. Rev Assoc Med Bras. 2014; 60(2):181-6.

6. Cervera R, Espinosa G. Antiphospholipid syndrome. Med Interna. 2018; 25(4):303-8.

7. Lopes MR, Danowski A, Funke A, Rêgo J, Levy R, de Andrade DC Update on antiphospholipid antibody syndrome. Rev Assoc Med Bras. 2017; 63(11):994-99.

\section{Corresponding author}

\section{Giovanna Maria Oliveira Ribeiro}

Juscelino Barbosa Street, 885, Alfenas, MG, Brazil.

Phone: (35) 99944-9775.

E-mail: giovannamariaoribeiro@gmail.com 